\title{
CGMP-Specific 3',5'-Cyclic Phosphodiesterase
}

National Cancer Institute

\section{Source}

National Cancer Institute. cGMP-Specific 3',5'-Cyclic Phosphodiesterase. NCI Thesaurus.

Code C95469.

cGMP-specific 3',5'-cyclic phosphodiesterase (875 aa, $100 \mathrm{kDa}$ ) is encoded by the human PDE5A gene. This protein plays a role in the mediation of cyclic GMP metabolism. 